\title{
Effects of dates (Phoenix Dactylifera Linn) on Blood Glucose Levels in Type-2 Diabetes Mellitus Patients
}

\author{
Erlyna Jayeng Wijayanti ${ }^{1}$, Eti Poncorini Pamungkasari ${ }^{2}$ and Sugiarto ${ }^{3}$ \\ \{erlyna79@student.uns.ac.id ${ }^{1}$, etiponco@staff.uns.ac.id ${ }^{2}$, sugiarto_sppd@yahoo.co.id ${ }^{3}$ \} \\ 1,2,3 Universitas Sebelas Maret, Surakarta, Indonesia
}

\begin{abstract}
Type-2 diabetes mellitus (DM) burdens health care costs when complications occurred. Dates (Phoenix dactylifera Linn) contain almost complete nutrients, fiber and rich in antioxidants, which can control blood glucose levels. This study aimed to determine the effect of dates on blood glucose levels. This was the experimental study with Randomized Control Trial Pretest and Posttest. There were 36 outpatients of type-2 DM, divided into two groups, control and treatment. 50 grams of Lulu dates were given to the treatment group a day, while the control group were not. In 14 days, all groups were continued to consume oral anti-diabetic drugs. Daily intake data were obtained from 24-hr recall questionnaires, nutritional status data obtained from anthropometric measurements while data of DM from blood glucose levels. Data analysis using the Paired t-test. Results showed that the difference in the decrease of blood glucose levels, in control group $(8.67 \mathrm{mg} / \mathrm{dl}$, p-value $=0.067)$ were lower than the treatment group $(22.94 \mathrm{mg} / \mathrm{dl}$, $\mathrm{p}$-value $=0.04)$. There were no significant decrease of blood glucose levels between control and treatment groups ( $\mathrm{p}$-value $=0.223$ ). In this study, consumption of dates has no significant effect on blood glucose levels, but further study are needed to know how dates can improve blood glucose levels.
\end{abstract}

Keywords: type-2 DM, blood glucose levels, dates

\section{INTRODUCTION}

DM is a silent killer, when complications have occurred and not realized by the patient [1]. Globally, diabetes mellitus burdens on the health care system. The development of DM is associated with lifestyle changes, environmental changes and healthy living behaviors [2, 3]. Type-2 DM is a chronic condition characterized by hyperglycemia due to the progressive loss of $\beta$ cell function and insulin resistance [4]. Indonesia's ranking of DM prevalence was the 5th in Asia Pacific [5]. According to Basic Health Research 2018, the prevalence of DM in Indonesia was $2.0 \%$, while East Java exceeds the national figures [6]. Type-2 diabetes mellitus can be prevented by reducing smoking, increasing exercise and lifestyle changes such as a healthy diet [2]. Type-2 diabetes mellitus is strongly associated with food, the highest cause of death [7].

Dates have very important benefits; all parts of dates are useful for human life. In parts of the leaves, fruit and pollen it functions as an antioxidant, anti-diabetic, anticancer, hepato- 
protective, nephro-protective and protective gastrointestinal [8]. Antioxidants in dates such as melatonin and polyphenol compounds can control blood glucose and lipids in DM patients by controlling digestion rate of carbohydrates [9]. $\alpha$-glycosidase blocks the hydrolysis of oligosaccharides, trisaccharides and disaccharides to glucose in small intestine, while $\alpha$ amylase inhibitors blocks the hydrolysis of oligosaccharides from complex starches. Dates also high in fructose, which does not require insulin and does not increase blood glucose levels, so it safe for diabetes [10]. The nutritional value of ten varieties of dates from Saudi Arabia was $1.72-4.73 \%$ protein; $0.12-0.72 \%$ fats and carbohydrates around $71.2-81.6 \%$ (the main sugars are glucose and fructose) [11]. One portion of dates $(3 \mathrm{pcs}=15 \mathrm{~g})$ equivalent to 1 medium size of banana $(50 \mathrm{~g}), 1 / 2$ large avocado $(50 \mathrm{~g}), 20$ grapes $(165 \mathrm{~g}), 1$ small red apple (85g), 1 medium apple (75g) which contains $50 \mathrm{kcal}$ and $10 \mathrm{~g}$ carbohydrates [12].

Several dates studies on mice induced by alloxan intravenously so that mice have type-2 $\mathrm{DM}$, then they were given extract of dates water, the results of these study showed that there were effects of dates on post-prandial 2-hr blood glucose levels (after meals) [13]. Intake of Ajwa and Sukkari variety dates in streptozotocin induced rats for four weeks also showed that dates can reduce fasting glucose levels even if not normal [14]. Munadi and Dedi's study used a combination of Ajwa dates and Banana in DM patients with insulin therapy and oral antidiabetic drugs for two weeks showed that consuming dates did not increase blood glucose levels, while there was no significant difference between consuming bananas and dates [15].

In Indonesia, the most popular dates are from Lulu variety. It tastes good, easy to get and lower prices. Studies on Ajwa dates is widely carried out, but only a few research for Lulu dates. The objection of this study was to determine the effect of dates on blood glucose levels in type-2 DM patients. Further studies needed for type-2 DM patients diet management.

\section{METHOD}

This was an experimental study with randomized control (RCT) with pretest and posttest control group design. This study was held in Pucang Sewu Health Center Surabaya in January 2019. There were 18 type- 2 diabetes mellitus outpatients of Pucang Sewu Health Center Surabaya which were aged 30-59 years and take an oral drugs glibenclamide or metformin. This study was approved by the Ethics Committee in Health Research of Medical Faculty of Universitas Sebelas Maret Surakarta with number: 377/UN27.6/KEPK/2018.

Amount 50g Lulu dates daily consumed in the morning, afternoon and evening before the main meal, by the treatment group in 14 consecutive days. Data of nutritional status obtained from anthropometric measurements, data of daily intake were obtained from 24-hr recall questionnaires (before, in the middle and in the end of the study). Data of DM obtained from blood glucose levels (after at least 8 hours fasting). Paired t-test and Mann Whitney were performed to analyze the differences of blood glucose level using statistical software of SPSS version 20.

\section{RESULTS AND DISCUSSIONS}

The majority subjects participated in this study were women $(86.1 \%)$, who aged $50-59$ years old (69.4\%). Age above 45 years has a higher risk of the incidence of DM due to degenerative factors that cause decreased of body function, especially the ability of $\beta$ cells to produce insulin [16]. According to the 24-hr food recall, carbohydrates intake of control group were lower than their all needs. 27.8 percent treatment group were had an adequate intake, while $72.2 \%$ were not. Fiber intake in both of control and treatment groups was lower than their all requirements. 
This study proves that fasting blood glucose levels in the treatment group before consuming dates $(190.44 \pm 43.76)$ and after consuming dates decreased to $(167.50 \pm 56.58)$ with the average of decrease were $22.94 \mathrm{mg} / \mathrm{dl}$. The results of the decrease in blood glucose levels in the first day control group of the study $(184.11 \pm 54.53)$ and the last day of the study $(175.44 \pm 57.56)$ with the average of decrease were $8.67 \mathrm{mg} / \mathrm{dl}(\mathrm{p}$ value $<0.05)$. This results showed that there were no differences of blood glucose levels between the control group and the treatment group in pretest $(p$-value $=0.517)$ and posttest $(p$-value $=0.776)$. In our study, dates effects blood glucose level, but it was not statistically significant.

This study in line with the study of Dalia et al. in STZ-induced diabetic rats, which given $1 \mathrm{~g} / \mathrm{Kg}$ body weight powdered dates from Egypt for 4 weeks. It showed that powdered dates reduced fasting blood glucose levels (but it cannot be normal), reduced total cholesterol (TC) and triglycerides (statistically not significance). Marghoob and Abdelmarouf study also found the significant decrease of blood sugar levels in STZ-induced mice (given dose $10 \mathrm{ml} / \mathrm{day}$ Ajwa and Sukkari dates which concentration $100 \mathrm{~g} / \mathrm{L}$ for 8 weeks) [14, 17]. Meanwhile, the study of Munadi and Dedi in type-2 DM patients with oral anti-diabetic drugs and get insulin and consumed $50 \mathrm{~g}$ of Ajwa dates was not significantly increases blood glucose levels [15].

Active compounds in dates such as flavonoids, steroids, phenolics and saponins besides function as antidotes to free radicals also act as anti-diabetic [18]. Dates can inhibit glucose absorption through the carbohydrate hydrolysis inhibitor enzymes such as $\alpha$-glucosidase and $\alpha$-amylase [19]. Hyperglycemia due to impaired of insulin secretion will inhibit $\alpha$-glycosidase and $\alpha$-amylase inhibitors which controlled blood glucose levels in type 2 diabetes mellitus. $\alpha$ glycosidase blocks the intestine glucose in the small intestine and $\alpha$-amylase block the hydrolysis of complex starches for oligosaccharides. This inhibition system reduces the rate of digestion of carbohydrates $[9,20]$. Regular intake of natural antioxidants such as glutathione and phenolic reduces the risk of several chronic diseases including cancer, diabetes and cardiovascular disease [21, 22].

Dates are a high source of fiber, both soluble and insoluble fiber. It contains cellulose, hemicellulose, pectin and lignin which are able to provide about $9-13 \%$ of the total daily fiber requirement or around $8 \mathrm{~g} / 100 \mathrm{~g}$ depends on the type of cultivar and the place of growth [23, 24 . 25]. Fiber will bind a lot of water and form a gel so that the possibility of glucose or cholesterol contact with the small intestine and coming and get into the blood becomes smaller. The less glucose in the blood and the less insulin produced, so that the blood glucose levels and cholesterol levels decrease [26].

In our study, dates effects blood glucose level, but it was not statistically significant. The possible factor because of daily fiber intake of subjects was lowered than requirements. Most of subject also has lower energy and nutrients intake due to their worry about consume adequate intake and the disease.

\section{CONCLUSIONS}

Type-2 diabetes mellitus can arise due to lifestyle and dietary changes such as consuming high-fat, low-fiber and fast-food that are not balanced in nutrients. Antioxidants content in dates inhibits blood glucose level which are potentially become one of non-pharmacological therapies. Daily intake of dates affects the decrease of blood glucose level that important to improve the health of DM patients. 


\section{REFERENCES}

[1] Ministry of Health Republic of Indonesia. Basic Health Research Report 2013. National Institute of Health Research and Development. Jakarta: Ministry of Health Republic of Indonesia, 2013.

[2] Mohieldein, A., Alzohairy, M., Hasan, M., Risk estimation of type 2 diabetes and dietery habits among adult Saudi non-diabetics in Central Saudi Arabia. Global Journal of Health Science, vol. 3, no. 2, pp. 123-133, 2011.

[3] Savolainen, O., Lind, M. V., Bergström, G., Fagerberg, B., Sandberg, A.-s., \& Ross, A., Biomakers of food intake and nutrient status are associated with glucose tolerance status and development of type 2 diabetes in older Swedish women. The American Journal of Clinical Nutrition, vol. 106, no. 5 pp. 1302-1310, 2017.

[4] Tanton, D., Duh, M. S., Lafeuille, M. H., Lefebvre, P., Pilon, D., Zhdanava, M., Bailey, R. A., Real-world evaluation of HbA1C, blood pressure, and weight loss among patients with type 2 diabetes mellitus treated with canagliflozin: an analysis of electronic medical records from a network of hospitals in Florida. Current Medical Research and Opinian, vol. 34, no. 6, pp. 1099-1115, 2018.

[5] International Diabetes Federation, IDF Diabetes Atlas, $6^{\text {th }}$ ed. Brussels, Belgium: International Diabetes Federation, 2013.

[6] Ministry of Health Republic of Indonesia. Basic Health Research Report 2018. National Institute of Health Research and Development. Jakarta: Ministry of Health Republic of Indonesia, 2018.

[7] Cradock, K. A., ÓLaighin, G., Finucane, F. M., McKay, R., Quinlan, L. R., Martin Ginis, K. A., Gainforth, H. L., Diet behavior change techniques in type 2 diabetes: A systematic review and meta-analysis. Diabetes Care, vol. 40, no. 12, pp. 1800-1810, 2017.

[8] Mallhi, T. H., Qadir, M. I., Ali, M., Ahmad, B., Khan, Y. H., Ur-Rehman, A., Review: Ajwa Date (Phoenix dactylifera): An Emerging Plant in Pharmacological Research. Pak. J. Pharm. Sci., vol. 27, no. 3, pp. 607-616, 2014.

[9] Girish T.K, Pratape V.M, Prasad Rao U.J.S, Nutrient distribution phenolic acid composition, antioxidant and alpha-glucosidase inhibitorypotentials of black gram (Vigna mungo L) and its milled by products, Food Res, vol. 46, pp. 370-377, 2012.

[10] Tappy, L, Lê KA., Metabolic effects of fructose and the worldwide increase in obesity. Physiol Rev, vol. 90, no. 1, pp. 23-46, 2010.

[11] Assirey, E. A. R., Nutritional composition of fruit of ten date palm (Phoenix dactylifera L.) cultivars grow on Saudi Arabia. Journal of Taibah University for Science, vol. 9, no. 1, pp. 75-79, 2014.

[12] Ministry of Health Republic of Indonesia. Regulation of Minister of Health Republic of Indonesia No. 41 about Balanced Nutrition Guidelines. Jakarta: Ministry of Health Republic of Indonesia, 2014.

[13] Kholidha, A.N., Hafizah, I., Wati, R. Effect of date palm extract (Phoenix dactylifera) on post prandial blood glucose sugar levels in mice (Mus muscular) induced by alloxan. National Seminar on Applied Quantitative Research. vol. 1, no.1, pp. 9-15, 2017.

[14] Dalia, H.A., Abdelaziz, Sahar, A.A., Mahmoud, M.A, Phoenix dactylifera seeds ameliorate early diabetic complications in streptozotocin-induced diabetic rats, Pharmaceutical Biology, vol. 53, no.6, pp.792-799.

[15] Munadi \& Ardinata, D., Changes in blood glucose levels of type 2 diabetes mellitus patients who are controlled after consuming dates. Majalah Kedokteran Nusantara, vol. 41, no. 1, 2008. 
[16] Betteng, R., D. Pangemanan, N. Maluyu. Analysis of risk factors of the causes of type 2 diabetes mellitus in productive age women at Wawonasa Health Center, Jurnal eBiomedik, vol. 2, 2014.

[17] Hasan, M. \& Mohieldein, A. In vivo evaluation of anti diabetic, hypolipidemic, antioxidative activities of Saudi date seed extract on streptozotocin induced diabetic rats, J. Clin Diagn Res, vol. 10, pp. 6-12, 2016.

[18] Michael, H.N., Salib, J.Y., Eskander, E.F. Bioactivity of diosmetin glycosides isolated from the epicarp of date fruits, Phoenix dactylifera, on the biochemical profile of alloxan diabetic male rats. Phytother Res, vol. 27, no. 5, pp. 699-704, 2013.

[19] Chakroun, M., Khemakhem, B., Mabrouk, H.B., El Abed, H., Makni, M. Bouaziz, M., Drira, N., Marrakchi, N., Mejdoub, H. Evaluation of anti-diabetic and anti-tumoral activities of bioactive compounds from Phoeniz dactylifera L's leaf: in vitro and in vivo approach. Biomed Pharmacother. vol. 84, pp. 415 - 422, 2016.

[20] El Abede H., Chakrouna M., Imed F., Maknib M., Bouazizc M., Driraa N., Mejdouba H., Khemakhema B., Extraction optimization and in vitro and in vivo anti-postprandial hyperglycemia effects of inhibitor from Phoenix dactylifera L. parthenocarpic fruit, Biomedicine \& Pharmacotherapy. vol. 88, pp.835-843, 2017.

[21] Tapiero, H., Tew, K., Nguyen Ba G., Mathe G., Polyphenols: do they play a role in the prevention of human pathologies?. Biomed pharmacother. vol. 56, no. 4, pp. 200-207, 2002.

[22] Duthie, G. G., Gardner, P. T., Kyle, J. A., Plant polyphenols: are they the new magic bullet? P, Nutr Soc, vol. 62, no. 3, pp. 599-603, 2003.

[23] Elleuch, M.S., Besbes, O.R. Date flesh: Chemical composition and characteristics of the dietary fibre. Food Chemistry, vol. 111, no. 3, pp. 676-682, 2008.

[24] Ali, A., Y.S.M. Al-Kindi, F. Al-Said. Chemical composition and glycemic index of three varieties of Omani dates. International Journal of Food Sciences and Nutrition, vol. 60, no. 4, pp. 51-62, 2009.

[25] Marlett, J.A. McBurney, M.I. Slavin, J.L. Position of the American Dietetic Association: health implications of dietary fiber, J Am Dietet Assoc, vol. 102, no.7, pp 993-1000, 2002.

[26] Queenan, K.M., Stewart, M.L., Smith, K.N., Thomas, W., Fulcher, R.G., Slavin, J.L., Concentrated oat $\beta$-glucan, a fermentbale fiber, lowers serum cholesterol in hypercholesterolemic adults in a randomized controlled trial, Nutrition Journal, vol. 6, no. 6, pp. 1-8, 2007. 